Indonesian Science Education Research
(ISER)

\title{
THE APPLICATION OF MODEL PROBLEM BASED LEARNING (PBL) AGAINST STUDENT RESULTS IN SENIOR HIGH SCHOOL 11 SAMARINDA
}

\author{
${ }^{1}$ Paulina Cerling, ${ }^{2}$ Muliati Syam, dan ${ }^{3}$ Muhammad Junus \\ ${ }^{1,2,3}$ Department of Physic Education Faculty of Teacher Training and Education Universitas \\ Mulawarman, Samarinda-Indonesia \\ paulinacerling@gmail.com
}

Accepted: September $5^{\text {th }}, 2020$. Published: October $6^{\text {th }}, 2020$

\begin{abstract}
This study aims to determine the increase in student learning outcomes of class XI IPA 1 senior high school 11 Samarinda after applying the PBL model to the Static Fluid material and to find out student responses about the application of the PBL model in static fluid learning. The research used One Group Pretest-Posttest Design method on Static Fluid material. The technique used was purposive sampling with the sample of this study were 35 students of class XI IPA 1 senior high school 11 Samarinda. The instruments used were written questions and questionnaires. Based on the results of the study showed that the average N-Gain was 0.69. The results of the t-test calculation showed that a significant level of learning outcomes and students' responses to PBL was in a good category or criteria.
\end{abstract}

Keywords: Model Problem Based Learning (PBL), Learning Outcomes, Student Responses 


\section{Introduction}

According to Law no. 20 of 2003 (Faturrahman, 2012) regarding the National Education System, Education is a conscious and planned effort to create a learning atmosphere and learning process so that students actively develop their potential to have religious spiritual strength, self-control, personality, intelligence, noble character, as well as the skills needed by himself, the community, the nation and the State.

Teaching and learning is a process of interaction (reciprocal relationship) between teachers and students or learning and the elements in it (Falestin and Ulfa, 2015). Learning is part of education, which is supported by various elements of learning, including objectives, subject matter, infrastructure, learning situations or conditions, learning media, learning environment, learning methods, and evaluation. All of these learning elements greatly influence the success of the teaching and learning process to improve student achievement (Anwar \& Khairina, 2014).

The teaching and learning process is influenced by two factors. The first factor is the factor that comes from within and the second factor is the factor that comes from outside the student, while the factor that comes from outside the student, one of which is the learning method. The use of the right method greatly affects the success of the learning process. However, the current reality is that there are still many teachers who used the lecture-recitation method in their learning process (Hakim, Sunarto, \& Totalia, 2016).

The phenomenon of failure to achieve the essence of learning, especially in improving the learning outcome process is because students are not treated as part of their realistic world in the learning process in class. the learning process that still relies on conventional methods does not make students emotionally active, education that often occurs in the field is colored by a learning model that is still teacher-centered (teacher center not student center), so that conditions that are less able to stimulate students to be actively involved in the learning process teaching, the lack of student activity in the learning process has implications on student learning outcomes.

The physics learning process is not sufficiently carried out by conveying information about concepts and principles, but students must also understand the process of physical phenomena by sensing as much as possible. This means that when learning science students must actively observe, conduct experiments, engage in discussions with peers or with teachers. Therefore teachers should be able to choose and apply learning models that are able to stimulate students to be more active in learning and increase students' abilities in understanding lessons.

Based on observations and interviews that have been conducted with physics subject teachers at senior high school 11 Samarinda, there are still many students who are less active in the physics learning process. Physics lessons also become monotonous and boring because learning is only teacher centered or uses The Direct Instruction learning.

Choosing the right learning model is a manifestation of a teacher's creativity so that students are not bored or bored in receiving lessons. Choosing the right learning model will also clarify the concepts given to students who are always enthusiastic about thinking and play an active role (Az Zahra \& Widiyanto, 2015). An effective learning model can be used by teachers to transfer knowledge properly and correctly, either directly or indirectly. The learning model will be efficient if it produces students' abilities as expected in terms of objectives and in accordance with the calculation targets in terms of material and time. A teacher should be able to choose the right model for their students (Rahayuningsih, 2015).

One of these models is the Problem Based Learning (PBL) learning model. It is expected that the PBL model will be more effective when compared to conventional methods. The effectiveness of this model is that students are more active in thinking and understanding the material in groups by conducting investigations and inquiries on real problems around them, so that they get a deep and more meaningful impression about what they are learning (Istiatutik, 2017). The 
PBL model is one of the learning models in which authentic assessment (real or concrete reasoning) can be applied comprehensively, because in it there is an element of finding a problem and solving it at the same time (the elements contained in it are problem posing or finding problems and problem solving or solving problems) (Indrianawati, 2013).

The purpose of PBL is to challenge students to pose problems and also solve problems that are more complicated than before, can increase student activity in expressing their opinions, foster cooperation and student cohesiveness in groups, develop student leadership and develop analytical pattern skills and can help students develop their reasoning processes. Problem-based teaching is used to stimulate higher-order thinking in problem-oriented situations, including learning how to learn. Problembased teaching cannot be implemented if the teacher does not develop a classroom environment that allows for an open exchange of ideas. In essence, students are faced with authentic and meaningful problem situations that can challenge students to solve them (Nurhadi, 2004).

\section{Research Method}

This research was a quantitative research. By using the design, the subject in this study was only one class as the experimental class group. This class will be given a pre-test before being treated in the form of a PBL learning model and then given a final test (post-test). The one group pretest-posttest design according to Sugiyono (2010) is described as follows:

Table 1. One-Groupe Pretest-Posttest.

\begin{tabular}{ccc}
\hline Pre-test & Treatment & Post-test \\
\hline $\mathrm{O}_{1}$ & $\mathrm{X}$ & $\mathrm{O}_{2}$
\end{tabular}

Information :

$\mathrm{O}_{1}$ : pre-test scores. (before treated)

$\mathrm{O}_{2}$ : Post-test scores (after treated).

$\mathrm{X}$ : The treatment provided by the Problem Based Learning model.

The sampling technique of this research was one of the classes taken by purposive sampling. Purposive sampling is sampling based on judgment or deliberate sampling according to the objectives in research conducted.

In this study the data collection techniques used were as follows:

1. Test technique

In accordance with this research, the data collection technique used was the test technique. The test used in this study was a pretest-posttest written test. The pre-test questions were given at the beginning of the lesson and the post-test questions were given at the end of the lesson. The post-test question was carried out to determine the learning outcomes of students after being treated in the form of the application of the PBL model with the aim of students finding or investigating every material taught at each meeting. In this test, it was made in accordance with the material taught to students. The test consists of 10 items in the form of an essay.

\section{Non-Test Techniques}

The data analysis technique used the $\mathrm{N}$-Gain test and paired t-test. The level of success of the pretest and posttest can be identified by looking for gain. Gain is the difference between the pretest and posttest scores, the gain refers to the level of improvement in student learning outcomes after the learning has been carried out. namely by using the following formula:

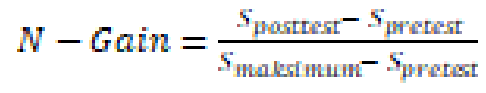

Information :

$$
\begin{array}{ll}
\mathrm{N}-\text { Gain } & : \text { Increase } \\
\text { Sposttest } & : \text { Total Posttest Score } \\
\text { Spretest } & \text { : Total Pretest Score } \\
\text { Maximum } & : \text { Total Score Maximum }
\end{array}
$$

It is explained here that $\mathrm{N}$-Gain is the normalized gain, $S_{\text {Maximum }}$ is the maximum (ideal) score of the initial and final tests, $\mathrm{S}_{\text {posttest }} \mathrm{a}$ is the final test score, while the $\mathrm{S}_{\text {pretest }}$ is the initial score. The level of normalized gain (N-Gain) can be categorized as follows:

Table 2. Identification of the Pretest-Posttest Level of Success Rate.

\begin{tabular}{cc}
\hline Value & Category \\
\hline $\mathrm{g}>0,7$ & Tinggi \\
\hline $0,3 \leq \mathrm{g}<0,7$ & Sedang \\
\hline $0 \leq \mathrm{g}<0,3$ & Rendah \\
\hline
\end{tabular}


To determine the application of the problem based learning model to the learning outcomes of students in senior high school 11 Samarinda, the study used paired t-test to pre-test and post-test score data in the class being tested. t-test testing needs to pay attention to the steps in answering the hypothesis as follows:

$$
H_{0}: \mu_{1}=\mu_{2}
$$

To test the hypothesis, the proposed hypothesis was eliminated first to become the test hypothesis $\left(\mathrm{H}_{0}\right)$ which reads:

$\mathrm{H}_{0}$ : There is no significant effect on the Problem Based Learning model on the learning outcomes of students in senior high school 11 Samarinda (Static Fluid Material). Systematically was used the following formula:

$$
t=\frac{x d-\mu}{s d f \sqrt{n}}
$$

(Riduwan, 2010)

Information :

$\mathrm{d}=$ the difference $\mathrm{x}_{1}-\mathrm{x}_{2}$

$\mathrm{n}=$ Number of samples

$\mathrm{xd}=$ Average deviation

$\mathrm{Sd}=$ Standard deviation from $\mathrm{d}$

$\mu=$ The average value of the difference in deviation

Testing through the t-test by comparing the t-count with the t-table at the real level $\alpha=0.05$. Decision making on the paired t-test is based on the significance value with SPSS. if the probability value (tcount> t-table) then there is a significant difference between the Problem Based Learning (PBL) learning model and the Learning Outcomes in the pre-test data and post-test data with a probability smaller than $5 \%(\mathrm{p}<0,05)$. whereas if the probability value (t-count $<\mathrm{t}$-table) then there is no significant difference between the Problem Based Learning (PBL) learning model on student learning outcomes in the pretest and posttest data.

3. Non-Test Techniques

Non-test techniques were used to determine student responses to the application of the PBL model during the learning process. The technique used was the collection of student response data using a questionnaire. The questionnaires collected were in the form of sheets containing positive and negative statements that have been adjusted to the steps of the PBL model. Questionnaire collection was carried out at the end of the learning activity. The number of statements in this questionnaire was 7 items.

\section{Result}

\section{Result and Discussion}

This research was conducted at senior high school 11 Samarinda from November 6th to November 21st 2019. The sample used in this study were 35 students of class XI MIPA 1, totaling 35 students (16 boys and 19 girls). physics teacher at senior high school 11 Samarinda with learning activities taking place twice a week, namely every Wednesday and every Thursday. Learning physics in class XI IPA 1 used a problem based learning model based on science process skills about Static Fluid material. Before the authors conducted the research, students had never learned to use the tools in the laboratory, so that students had difficulty recognizing the tools used.

\section{Pretest average}

Through a formative test, namely the initial ability test (pretest) with an essay test of 10 items. The pretest data for class XI MIPA 1 students of senior high school 11 Samarinda were obtained before applying the Problem-based learning model. Based on the pretest data, the students' average scores were obtained as follows:

$$
\bar{X}=\frac{1115}{35}=31,85
$$

These results indicate that the overall pretest mean score of students was categorized as very low. When compared with the minimum completeness criteria $(\mathrm{KKM})$ in Physics, the average pretest results for class XI MIPA 1 senior high school 11 Samarinda were still below the standards that set by the school, which is 70 .

Based on the pretest scores of class XI MIPA 1 students can be classified into categories of assessment based on data such as: 
Table 3. Percentage of Student Learning Outcomes Assessment (Pretest)

\begin{tabular}{cccc}
\hline Mark & Information & $\begin{array}{c}\text { Frequenc } \\
y\end{array}$ & Presentase \\
\hline $80-100$ & Very Good & 0 & $0 \%$ \\
\hline $66-79$ & Good & 0 & $0 \%$ \\
\hline $56-65$ & Enough & 1 & $2,85 \%$ \\
\hline $40-55$ & Bad & 10 & 28.57 \\
\hline $0-39$ & Very Bad & 24 & $68 \%$ \\
\hline
\end{tabular}

Based on table 3 above, the acquisition of student learning outcomes can be shown in the following graph:

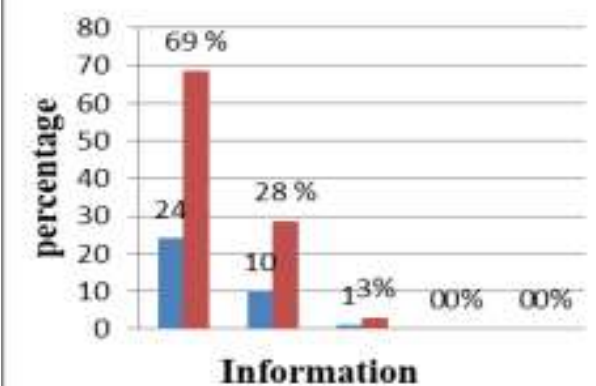

Figure 1. Graph of Average Student Learning Outcomes (Pretest)

Based on the pretest value, it shows that overall the students of class XI MIPA 1 are declared incomplete, because no student has reached the minimum completeness criteria (KKM) score in physics subjects of 70. Based on the analysis and calculation process, the student's pretest data can be presented in the following table:

Table 4. Students' results in pretest learning outcomes

\begin{tabular}{cccc}
\hline $\begin{array}{c}\text { Value } \\
\text { Interval }\end{array}$ & Information & Frekuensi & Percentage \\
\hline $0 \leq \mathrm{N}<70$ & Not Pass & 35 & $100 \%$ \\
\hline $\begin{array}{c}70 \\
\leq \mathrm{N} \leq 100\end{array}$ & Pass & 0 & $0 \%$ \\
\hline
\end{tabular}

\section{Post-test average}

Through a formative test which was conducted again by the researcher, to retrieve data on student learning outcomes after the application of problem-based learning model learning or post-test data for class XI MIPA 1 students of senior high school 11 Samarinda. Researchers used a test with the same question form and number of questions as the previous pre-test.

$$
\bar{X}=\frac{2702}{35}=77,20
$$

These results indicate that the overall post-test mean score of the students was categorized as good. When compared with the minimum completeness criteria (KKM) in Physics, the average post-test score of class X1 MIPA 1 senior high school 11 Samarinda was above the KKM standard set by the school, which is 70. Based on the post-test score Class XI MIPA 1 students can be classified in the category of assessment based on data such as:

Table 5. Percentage of learning outcomes assessment (posttest)

\begin{tabular}{llll}
\hline Nilai & keterangan & frekuensi & presentase \\
\hline $80-100$ & Very Good & 15 & $42,86 \%$ \\
\hline $66-79$ & Good & 18 & $51,43 \%$ \\
\hline $56-65$ & Enough & 2 & $5,71 \%$ \\
\hline $40-55$ & Bad & 0 & $0 \%$ \\
\hline $0-39$ & Very Bad & 0 & $0 \%$ \\
\hline
\end{tabular}

Based on table 5 above, student learning outcomes can be shown in the following graph:

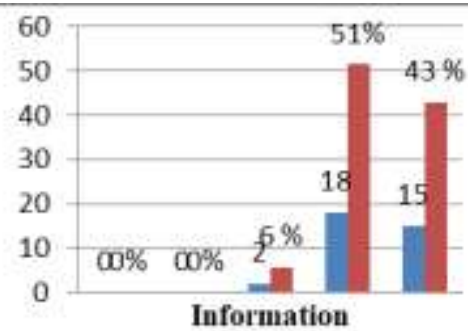

Figure 2. Graph of Average Student Learning Outcomes (Posttest)

Table 6. Completeness of Post-test Student Learning Outcomes

\begin{tabular}{llll}
\hline $\begin{array}{l}\text { Interval } \\
\text { nilai }\end{array}$ & Information & Frequency & $\begin{array}{l}\text { Percentag } \\
\mathrm{e}\end{array}$ \\
\hline 0 & & \\
$\leq N \leq 70$ & $\begin{array}{l}\text { Belum } \\
\text { tuntas }\end{array}$ & 6 & $17,14 \%$ \\
\hline 70 & & \\
\hline$\leq N \leq 100$ & Tuntas & 29 & $82,86 \%$
\end{tabular}


Based on the table of post-test scores, 6 students were declared not passed and 29 students passed.

\section{Student N-Gain Results}

the N-Gain value can be seen from the average score of the students' pretest and posttest. Student learning outcomes data on the subject matter of static fluids in class X1 MIPA 1 senior high school 11 Samarinda with 35 students obtained the results of the pretest and posttest, it was showed that there are 13 students who were at high category and 22 students were in the medium category. For more details N-Gain student learning outcomes can be seen in the following table:

Table 7. N-Gain Categories for Student Learning Outcomes

\begin{tabular}{ccccc}
\hline No & Range & Information & Frequency & $\begin{array}{c}\text { Percen } \\
\text { tage }\end{array}$ \\
\hline 1 & & & & \\
\hline & $\begin{array}{c}\mathrm{N}- \\
\text { gain } \\
\geq 0,7\end{array}$ & High & 13 & $37 \%$ \\
& & & \\
\hline 2 & $0,3 \leq \mathrm{N}$ \\
& gain $\leq$ \\
& 0,7 & Medium & 22 & $63 \%$ \\
\hline 3 & $\mathrm{~N}-$ & Low & 0 & $0 \%$ \\
& $\begin{array}{c}\text { gain }< \\
0,3\end{array}$ & & & \\
& & & \\
\hline
\end{tabular}

Based on the data in table 7 above, the percentage increase in student learning outcomes can be presented in the form of a graphic as follows:

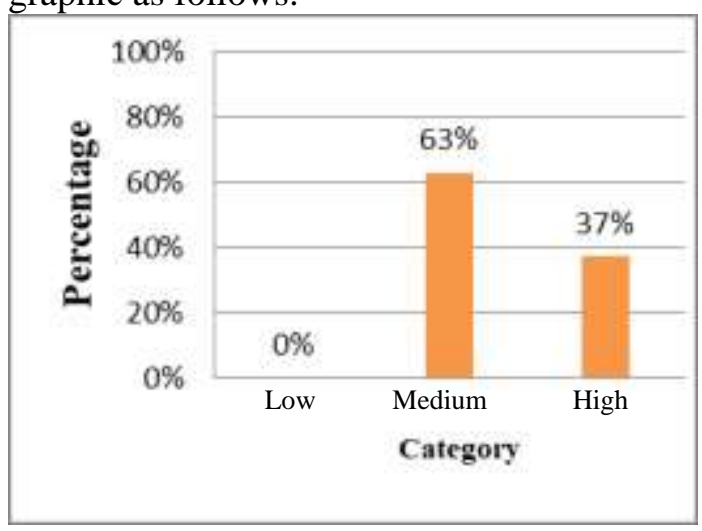

\section{Hypothesis testing (paired test)}

Paired t-test was carried out in this study to determine whether there was a difference in effect before learning with a problem-based learning model and after being given a problem-based learning model on student learning outcomes in class XI MIPA 1 senior high school 11 Samarinda, so that the t-test results could be seen in the following table:

Table 8. Results of Paired t-Test Analysis

\begin{tabular}{|c|c|c|c|c|c|c|c|c|}
\hline & \multicolumn{5}{|c|}{ Paired Difference } & \multirow[b]{3}{*}{$\mathrm{T}$} & \multirow[b]{3}{*}{ Df } & \multirow{3}{*}{$\begin{array}{l}\text { Sig. } \\
(2- \\
\text { tailed } \\
\quad)\end{array}$} \\
\hline & \multirow[b]{2}{*}{ Mean } & \multirow{2}{*}{$\begin{array}{l}\text { Std. } \\
\text { Devi } \\
\text { ation }\end{array}$} & \multirow{2}{*}{$\begin{array}{c}\text { Std. } \\
\text { Error } \\
\text { Mean }\end{array}$} & \multicolumn{2}{|c|}{$\begin{array}{l}\text { 95\% Confidence } \\
\text { Interval of the } \\
\text { Difference }\end{array}$} & & & \\
\hline & & & & Lower & Upper & & & \\
\hline $\begin{array}{l}\text { Pretest- } \\
\text { posttest }\end{array}$ & $\begin{array}{r}- \\
45.342 \\
86\end{array}$ & $\begin{array}{r}13.0 \\
7657\end{array}$ & $\begin{array}{r}2.2103 \\
4\end{array}$ & $\begin{array}{r}49.834 \\
82\end{array}$ & $\begin{array}{r}40.850 \\
90\end{array}$ & $\begin{array}{r}- \\
20 . \\
51 \\
4\end{array}$ & 34 & .000 \\
\hline
\end{tabular}

known that the significance value obtained is 0.000 and the $\mathrm{t}$-count value is $20.514 \mathrm{t}$ table value of 1.691 with $\mathrm{df}=34$ with a significant level of 0.05 is 1.690092 . So, the value of $\mathrm{t}$-count $>\mathrm{t}$-table. This means that there is a significant influence between the Problem Based Learning model on student learning outcomes.

\section{Questionnaire data analysis}

Students' responses to learning activities by applying the PBL model were known through observation in the form of statements in a questionnaire consisting of 7 statements using a Likert scale. These statements have been adapted to the steps of the PBL model.

Table 9. Results of the Student Response Questionnaire Analysis of the PBL Model

\begin{tabular}{ccc}
\hline Kategori & Frekuensi & Persentase \\
\hline Verygood & 0 & $0 \%$ \\
\hline Good & 19 & $54,28 \%$ \\
\hline Enough & 16 & $45,71 \%$ \\
\hline Bad & 0 & $0 \%$ \\
\hline Verybad & 0 & $0 \%$ \\
\hline
\end{tabular}

\section{Discussion}

This study aims to determine student learning outcomes using the application of the problem based learning model and to determine the increase in learning outcomes of high school students after applying the problem based learning model to the Static 
Fluid material. The population taken from this study were all students of class XI IPA Senior high school 11 Samarinda in the 2018/2019 academic year, totaling 3 classes. The samples were taken using purposive sampling technique, namely sampling selected with certain considerations. The samples taken in this study were 1 class, namely class XI MIPA 1, which amounted to 35 students.

Before carrying out the learning with Static Fluid material, a pre-test was given at the first meeting. The existence of this pre-test was in order to find out the students' initial ability to the Static Fluid material by taking an essay test of 10 items. From the results of these answers, the authors obtained preliminary data on student learning outcomes. After the pre-test was carried out, then students were given learning treatment with the problem-based learning model given at the first meeting, the teacher will provide material about hydrostatic pressure before entering the material. The teacher will convey the learning objectives with the aim that students understand the subject matter that will be understood together then the teacher will divide students into several groups one group consisting of 5-6 teachers presenting problems related to hydrostatic pressure contained in the LKPD 01 attachment, the teacher presents questions in the form of hypotheses contained in LKPD 01, the teacher will give students the opportunity to learners to ask things that are not understood, the teacher will guide students in determining hypotheses that were relevant to the problems presented, the teacher guides students to make observations and experiments, the teacher prepares tools and materials and guides them to conduct intermittent experiments. Furthermore, the teacher will guide students in group discussions then one of the representatives from each group will present the work of the group, the last stage the teacher will reflect on the material that has been delivered and provide feedback on the material presented and provide reinforcement for problem solving and at the closing stage the teacher does learning evaluation, providing positive advice and direction, the teacher concludes the learning material regarding hydrostatic pressure, then the teacher will deliver material for the next meeting with the subject matter of Pascal's Law, Archimedes Law and Surface Tension using the same learning steps as the first meeting. After all the material is submitted, a final test (posttest) will be carried out to obtain the final data of the students.

This research was conducted in 4 meetings, the research was started on November 7th, 2019 to November 20th, 2019. The physics learning schedule is on Wednesday (10.45 am - $12.15 \mathrm{am})$ and Thursday (10.45 am - $12.15 \mathrm{am}$ ).

At the first meeting the teacher asked students to work on the pretest questions which contained 10 items. Based on the data obtained, the average percentage of students completeness is $100 \%$ incomplete or not passed. This means that all students get a score below 70 because the KKM used at senior high school 11 Samarinda was 70.

Based on the results of the analysis of research data before students were taught using the Problem Based Learning learning model, in table 3. it is found that the pre-test average is 31.85 with a very poor or incomplete category, which can be qualified based on students with very low qualifications of $68,00 \%$ with a total of 24 students, students with less qualifications of $28.57 \%$ with a total of 10 students, students with sufficient qualifications of $2.85 \%$ with a total of 1 student, students with good qualifications of $0 \%$ with a total of 0 students and students with qualifications very good at $0 \%$ with a total of 0 students. This shows that the initial ability of students before being given learning using problembased learning models was relatively low because students are still used to using conventional learning models.

After the material has been taught by using the Problem Based Learning Model, then the writer conducted a final test (post-test) to see the student's ability to the material being taught by looking at student learning outcomes. Then, the researcher processed the data on student learning outcomes and student learning outcomes. In the category of student learning outcomes 
was divided into 5 parts, namely: very good $42.86 \%$ with a frequency of 15 people, good $51.43 \%$ with a frequency of 18 people and enough 5.71 with a frequency of 2 people, in the category the level of student completeness was divided into two parts namely: complete and incomplete. From the data analysis, it was obtained that the learning outcomes of students who completed $82.86 \%$ with a frequency of 29 people while $17.14 \%$ were not yet complete with a frequency of 6 people with a KKM standard is 70 . This showed that the learning outcomes obtained by students using the Problem Based Learning model had a positive and good effect on learning outcomes.

In particular, the effect of the application of the Problem Based Learning model on student learning outcomes was measured using pre-test and post-test which can be seen in table 7, which aims to determine the level of student success before and after the learning process which was analyzed through Normalizad-Gain (N-Gain. ). N-Gain is a test that provides an overview of improving student learning outcomes between before and after the learning process. N-Gain can be calculated using a formula, and the results of the calculation can be categorized as getting a medium category of $63 \%$ with a frequency of 22 people and a high $37 \%$ with a frequency of 13 people. -an average of 0.69 which was included in the medium category, it can be seen that the more frequent and interesting application of problem based learning models will increase in student learning abilities so that student curiosity will increase in the material taught and student learning outcomes will be better.

Furthermore, hypothesis testing has been carried out with paired t-test analysis in this study to determine whether there is a difference before the problem-based learning model was carried out and after the problem-based learning model was given to the learning outcomes of students in class XI MIPA 1 Senior high school 11 Samarinda as seen in the results pre-test and post-test. The results of data analysis using the problembased learning model, which resulted in significant pre-test and post-test scores, namely 0.000 . The calculation of the pre-test and post-test mean value test shows the $\mathrm{t}$ count value of 20.514, while for the t-table price $\mathrm{df}=34$ with a significant level of 0.05 is 1.69092 for the calculation of learning outcomes. The t-count value that was greater than the t-table causes $\mathrm{H}_{\mathrm{a}}$ to be accepted and $\mathrm{H}_{0}$ to be rejected. Based on this analysis, it has been proven that there was a significant difference between the average pre-test and post-test results of student learning outcomes after being given treatment in the form of a problem based learning model, which means that there is a significant effect on the problem based learning model on the results. student learning.

From the description above, the results of the research are in accordance with the statement of Trianto (2010) which states that the PBL model is a learning model that involves students to solve problems through the stages of the scientific method so that students learn knowledge related to these problems and at the same time have the skills to solve problems. So that in the research it appears that the problem based learning model that students get during learning by working on worksheets and direct observation can improve student learning outcomes in class XI MIPA 1 Senior high school 11 Samarinda on static fluid material.

At the end of the lesson, the researcher gave a questionnaire to students, the purpose of which was to give this questionnaire to find out the students' responses after being taught using the Problem Based Learning (PBL) model. The questionnaire used in this study was a Likert rating scale, where students answered statements with the choice of strongly disagree (STS), disagree (TS), quite agree (CS), agree (S), and strongly agree (SS). ) This questionnaire consists of 7 statements.

Based on the data analysis above, it has been proven that the effect before and after applying the Problem Based Learning (PBL) learning model in improving student learning outcomes in learning Physics in Static Fluid Material class X1 MIPA 1 senior high school 11 Samarinda. From the students' responses to the questionnaire given, the students gave a response that the 
PBL model had a good impact on the Physics subject. This learning model was able to create a good, interesting and effective atmosphere so as to encourage activity or activeness so that it was able to keep students always concentrating.

For student responses to the application of the PBL learning model on static fluid material grouped based on the nature of the statements given. In the student response statement from those who gave very good responses $0 \%$, good $54.29 \%$, enough $45.71 \%$, less $0 \%$ and very less $0 \%$. so that the authors can conclude that the Problem Based Learning learning model can help students in understanding physics lessons actively in learning this is due to a more active learning atmosphere because the syntax of the problem based learning model results in motivation appearing both from within and from outside the student. This is in accordance with the theory presented by Rita Magdalena (2016) that the application of the PBL model can improve learning outcomes.

\section{Conclusion}

Based on the results of research and data analysis that has been carried out in class XI MIPA 1 senior high school 11 Samarinda regarding the ability of student learning outcomes using the Problem Based Learning model on static fluid material, it can be concluded that:

1. Student Learning Outcomes in class X1 MIPA 1 at SMAN II Samarinda on the Static Fluid material after the implementation of the Problem Based Learning (PBL) Model increased learning outcomes where we can see the results on $\mathrm{N}$-Gain are in the moderate category, namely $63 \%$

2. The response of SMA II students to the application of the PBL model to the static fluid material is in the Good category or criteria

Based on the research results and conclusions, there were suggestions that can be given, namely the results of this study can be used as information material for students and researchers. The teacher can make the Problem Based Learning (PBL) model as an alternative strategy for learning physics in schools. There needs to be further research on the use of the Problem Based Learning (PBL) model and compared to other learning models. For schools, please have laboratory facilities equipped with practicum tools.

\section{Reference}

Amir, M. (2009). Inovasi Pendidikan melalui Problem Based Learning. Jakarta: Pernada Media Grup.

Anwar dan Kharisma. (2014). Meningkatkan Hasil Belajar Siswa Melalui model Pembelajaran Problem Based Learning pada Pembelajaran IPA Materi pokok zat dan wujudnya dikelas 1V SD Negeri 064977 Bhayangkara. Jurnal history home $>$ vol.2 No 1 .

Aunurrahman. (2009). Belajar dan Pembelajaran. Bandung: Alfabeta.

Faturraman, d. (2012). Pengertian pendidikan . Jakarta : PT. Prestasi Pustakarya.

Giancolli, D. (2001). Fisika edisi kelima Jilid 1. Jakarta: Erlangga.

Gunawan, M. A. (2013). Statistik untuk Penelitian Pendidikan. Yogyakarta: Parama Publishing.

Hamalik, O. (2012). Kurikulum dan Pembelajaran. Jakarta: Bumi Aksara.

Kangihan, M. (2017). Fisika untuk SMA/MA Kelas $X 1$. Jakarta : Erlangga.

Mudjiono dan, D. (2006). Belajar dan Pembelajaran. jakarta: Rineka Cipta.

Nurhadi. (2004). Pembelajaran Kontekstual dan penerapan dalam KBK. Malang: UM Press.

Rita, M. (2016). Penerapan Model Pembelajaran Problem Based Learning (PBL) Serta Pengaruhnya terhadap Hasil Belajar Biologi siswa SMA Negeri 5 Kelas X1 Kota Samarinda Tahun Ajaran 2015. Proceeding Biologi Education 
Conference(ISSN:2558-5742), Vol 13(1), 299-306.

Riduwan. (2010). Dasar-Dasar Statistik. Bandung: Alfabeta.

Rusman. (2010). Model- model Pembelajaran. Jakarta: PT Raja Grafindo Persada.

Rusman. (2014). Model-model Pembelajaran . Jakarta: PT.Raja Grafindo Persada.

Siregar, E. (2010). Teori Belajar Pembelajaran. Bogor: Ghalia Indonesia.

Sudjana Nana. (2013). Penilaian Hasil Proses Belajar Mengajar. Bandung: PT Remaja Rosda Karya.

Sugiyono. (2013). Metode Penelitian Kuantitatif,Kualitatif dan $R \& \quad D$. Bandung: Alfabeta.

Trianto. (2010). Mendesain Model Pembelajaran Inovatif -Progresif . Jakarta: Kencana.

Trianto. (2014). Mendesain Model Pembelajaran Inovatif,Progresif dan Kontekstual. Jakarta:Premedia Grup. 